\section{Advanced Glass-Ceramic Materials for Biomedical Applications}

\author{
Received: January 21, 2017; Accepted: January 24 2017; Published: January 28, 2017
}

\section{Michelina Catauro and Flavia Bollino}

\author{
Department of Industrial and Information \\ Engineering, University of Campania "Luigi \\ Vanvitelli", Aversa (CE), Italy
}

\section{Corresponding author: Michelina Catauro \\ michelina.catauro@unicampania.it}

Department of Industrial and Information Engineering, University of Campania "Luigi Vanvitelli", Aversa (CE), Italy.

Tel: 081-5010-360

Citation: Catauro M, Bollino F. Advanced Glass-Ceramic Materials for Biomedical Applications. J Bone Rep Recomm. 2017, 3:1.

surface stimulates hydroxyapatite nucleation, promoting their easier Osseo integration. Sol-gel glasses and ceramics have been proposed for many biomedical applications, such as artificial dental roots, bone regenerative materials, coatings to improve biological performance of bio inert implants and drug delivery systems [7-12]. In particular, silica, calcium silicate and calcium phosphate glasses and ceramics are attracting interest due to their ability to stimulate osteogenesis via both their dissolution and degradation products [10]. Indeed, soluble silica and calcium ions are able to activate and stimulate osteoprogenitor cells at the implant site, promoting bone tissue growth. These materials have also demonstrated the ability to form hydroxyapatite on their surface in vitro $[13,14]$. However, the brittleness of sol-gel materials limits their use in several load-bearing applications. To overcome these problems, many strategies have been proposed. The sol-gel method is easily coupled with different coating techniques like spray coating, spin coating and dip coating for the surface modification of bio inert implants with the aim of inhibiting wear, reducing corrosion and improving biological properties, as bioactivity and biocompatibility [15]. This allows the optimization of surface properties while retaining favourable bulk properties of the bio inert implants used. Recently, polymerbased composite materials, consisting of poly ( $\varepsilon$-caprolactone) in which inorganic sol-gel fillers are embedded, have been proposed $[16,17]$ to develop composite 3D scaffolds. This strategy allows the mechanical performance of the neat $\mathrm{PCL}$ to be improved and, at the same time, advantage to be taken of the well-known 
bioactive features of inorganic sol-gel particles. Moreover, the low processing temperatures of the sol-gel method allows thermo labile molecules (e.g. polymers, drugs, biomolecules, etc.) to be entrapped in the inorganic glassy matrix, making the sol-gel processes an ideal technique to prepare organic-inorganic hybrid (OIH) materials. The leading idea in their development has been to combine the favourable properties of each individual component forming the hybrid, and at the same time attempting to decrease or eliminate each component's drawbacks through a synergistic effect, thus resulting in a generation of new materials with new properties. Several OIH systems, consisting of an inorganic matrix in which a polymer and a drug were encapsulated, have been proposed as drug delivery systems. In this case, the polymer displays a dual function: improving the mechanical properties of the glassy matrix and modulating the release kinetics of the drug by the sol-gel matrix [18]. 


\section{References}

1 Kokubo T (1991) Bioactive glass ceramics: properties and applications. Biomaterials 12: 155-163.

2 Hench LL, Splinter RJ, Allen WC, Greenlee TK (1972) Bonding mechanism at interface of ceramic prosthetic materials. J Biomed Mater Res 2: 117-141.

3 Radev L, Hristov V, Michailova I, Fernandes MHV, Salvado IMM (2010) In vitro bioactivity of biphasic calcium phosphate silicate glass-ceramic in $\mathrm{CaO}-\mathrm{SiO}_{2}-\mathrm{P}_{2} \mathrm{O}_{5}$ system, Process. Appl Ceram 4: 15-24.

4 Kokubo T, Shigematsu M, Nagashima $Y$, Tashiro M, Nakamura T, et al. (1982) Apatite and wollastonite containing glass-ceramics for prosthetic application. Bull Inst Chem Res 60: 260-268.

5 Vallet-Regí M (2001) Ceramics for medical applications. J Chem Socie Dalto Transact pp: 97-108.

6 Gupta R, Kumar A (2008) Bioactive materials for biomedical applications using sol-gel technology. Biomed Mater 3: 034005.

7 Catauro M, Papale F, Roviello G, Ferone C, Bollino F, et al. (2014) Synthesis of $\mathrm{SiO}_{2}$ and $\mathrm{CaO}$ rich calcium silicate systems via sol-gel process: Bioactivity, biocompatibility, and drug delivery tests. J Biomed Mater Res A 102: 3087-3092.

8 Vallet-Regi M, Balas F (2008) Silica materials for medical applications. Open Biomed Eng J 2: 1-9.

9 Catauro M, Bollino F, Papale F, Vecchio Ciprioti S (2015) Investigation on bioactivity, biocompatibility, thermal behavior and antibacterial properties of calcium silicate glass coatings containing Ag. J NonCryst Soli 422: 16-22.

10 Midha S, Kim TB, Bergh WVD, Lee PD, Jones JR (2013) Preconditioned 70S30C bioactive glass foams promote osteogenesis in vivo. Acta Biomater 9: 9169-9182.
11 Catauro M, Bollino F, Renella RA, Papale F (2015) Sol-gel synthesis of $\mathrm{SiO}_{2}-\mathrm{CaO}-\mathrm{P}_{2} \mathrm{O}_{5}$ glasses: Influence of the heat treatment on their bioactivity and biocompatibility. Ceram Internat 41: 12578-12588.

12 Catauro M, Nunziante SP, Papale F, Bollino F (2015) Preparation of 0.7 $\mathrm{SiO}_{2} \bullet 0.3 \mathrm{CaO} / \mathrm{PCL}$ hybrid layers via sol-gel dip coating for the surface modification of titanium implants: characterization, bioactivity and biocompatibility evaluation. J Sol-Gel Sci Tech 76: 241-250.

13 Catauro M, Bollino F, Papale F, Gallicchio M, Pacifico S (2015) Influence of the polymer amount on bioactivity and biocompatibility of $\mathrm{SiO}_{2} / \mathrm{PEG}$ hybrid materials synthesized by sol-gel technique. Mater Sci Eng 48: 548-555.

14 Catauro M, Papale F, Bollino F (2016) Coatings of titanium substrates with $\mathrm{xCaO} \bullet(1-\mathrm{x}) \mathrm{SiO}_{2}$ sol-gel materials: characterization, bioactivity and biocompatibility evaluation. Mater Sci Eng 58: 846-851.

15 Catauro M, Papale F, Bollino F (2015) Characterization and biological properties of $\mathrm{TiO}_{2} / \mathrm{PCL}$ hybrid layers prepared via sol-gel dip coating for surface modification of titanium implants. J Non-Crys Solid 415: 9-15.

16 Santis RD, Gloria A, Russo T, Amora UD, Antò VD (2013) Advanced composites for hard-tissue engineering based on PCL/organicinorganic hybrid fillers: From the design of 2D substrates to 3D rapid prototyped scaffolds. Poly Comp 34: 1413-1417.

17 Russo T, Gloria A, Antò VD, Amora UD, Ametrano G (2010) Poly( $\varepsilon$ caprolactone) reinforced with sol-gel synthesized organic-inorganic hybrid fillers as composite substrates for tissue engineering. J Appl Biomater Biomech 8: 146-152.

18 Catauro M, Bollino F, Papale F, Piccolella S, Pacifico S (2016) Sol-gel synthesis and characterization of SiO2/PCL hybrid materials containing quercetin as new materials for antioxidant implants. Mater Sci Eng 58: 945-952. 